\title{
Article
}

\section{A new species of Bertiella (Melanommataceae) from Brazil and a key to accepted species}

\author{
Almeida DAC ${ }^{1 *}$, Gusmão $\mathrm{LFP}^{1}$ and Miller $\mathrm{AN}^{2}$ \\ ${ }^{1}$ Universidade Estadual de Feira de Santana, Av. Transnordestina, S/N - Novo Horizonte, 44036-900. Feira de \\ Santana,BA, Brazil.daviaugusto@gmail.com \\ ${ }^{2}$ Illinois Natural History Survey, University of Illinois, 1816 S. Oak St., Champaign, IL 61820.
}

Almeida DAC, Gusmão LFP and Miller AN 2017 - A new species of Bertiella (Melanommataceae) from Brazil and a key to accepted species. Mycosphere 8(4), 392-396, Doi 10.5943/mycosphere/8/4/1

\begin{abstract}
During an inventory of ascomycetes in the semi-arid region of Brazil, an undescribed specimen of Bertiella was found. It is described and illustrated as B. gelatinosa sp. nov., based on morphological data. The new fungus is distinguished by the size of the ascospores, which are surrounded by a gelatinous sheath. A synoptic table and a key to all known species of Bertiella are presented.
\end{abstract}

Key words - Ascomycota - Dothideomycetes - Pleosporales - Taxonomy

\section{Introduction}

Bertiella (Sacc.) Sacc. \& P. Syd. was elevated to the rank of genus by Saccardo \& Sydow (1899) after being described as a subgenus in Bertia De Not. This small genus is characterized by superficial, subglobose ascomata and bitunicate, cylindric-clavate, short-stalked asci containing eight fusiform, septate, hyaline ascospores (Table 1). It was considered a synonym of Massarina Sacc. by Eriksson \& Yue (1986), who examined the holotype of the type species, Bertiella macrospora (Sacc.) Sacc. \& Traverso, but this synonymy has not been widely accepted (Lumbsch \& Huhndorf 2007, Mugambi \& Huhndorf 2009, Lumbsch \& Huhndorf 2010, Zhang et al. 2012b, Hyde et al. 2013). Morphologically, these genera differ mainly by the position of the ascomata on the substrata, being immersed or erumpent in Massarina and superficial in Bertiella. Moreover, Hyde et al. (2002) assigned Bertia macrospora to Lophiostoma as L. bertiellum Aptroot \& K.D. Hyde. Phylogenetic studies indicated that those genera should be kept separate since they belong to different families. Bertiella was previously placed in the family Teichosporaceae (Lumbsch \& Huhndorf 2007), but molecular phylogenetic studies have found its placement in Melanommataceae (Mugambi \& Huhndorf 2009, Tian et al. 2015, Hyde et al. 2016). Massarina eburnea, the type species of Massarina, belongs in Massarinaceae, while the type of Lophiostoma, L. macrostomum (Tode) Ces. \& De Not., is phylogenetically placed in Lophiostomataceae (Mugambi \& Huhndorf 2009, Zhang et al. 2012a).

Six species have been described in Bertiella, but only four are currently accepted (http://www.indexfungorum.org). Bertiella brenckleana Rehm was transferred to Rosenscheldia 
Speg. by Thiessen \& Sydow (1915), while Bertiella polyspora Kirschst. was placed in Kirschsteinia Syd. \& P. Syd. by Sydow \& Sydow (1906). All accepted species are saprobic on lignicolous substrates (Morgan 1904, Eriksson \& Yue 1986) and are predominantly known from the north temperate zone (Berkeley 1876, Eriksson \& Yue 1986, GBIF 2016).

In this study, we present a description and illustrate a new species of Bertiella isolated from dead branches in Brazil, as well as a key and synoptic table (Table 1) to the accepted species.

\section{Materials \& Methods}

Samples of dead branches on the ground were collected in May 2012 at Ubajara National Park, Ceará State, and placed in paper bags. They were transported to the laboratory at the State University of Feira de Santana where they were examined for the presence of ascomata. The description of the area and methods for morphological examination can be found in Almeida et al. (2014). It was not possible to extract DNA because attempts to culture the fungus failed and very few ascomata occur on the substrata to try extraction directly from them. The holotype was deposited in the Herbarium of the State University of Feira de Santana (HUEFS).

\section{Results}

\section{Taxonomy}

Bertiella gelatinosa D.A.C. Almeida, Gusmão \& A.N. Mill., sp. nov.

MycoBank MB818725

Etymology - Referring to the gelatinous sheath covering the ascospores.

Holotype - HUEFS 131229.

Saprobic on decayed branch of unidentified plant. Sexual morph: Ascomata 100-220 $\mu \mathrm{m}$ high, 200-550 $\mu \mathrm{m}$ diameter, superficial, gregarious or solitary, discoid to subglobose or irregular shape, dark brown, surface roughened. Pseudoparaphyses 2-3 $\mu \mathrm{m}$ wide, hyaline, filiform, septate. Asci 124-188 × 14-22 $\mu \mathrm{m}, 8$-spored, bitunicate, clavate, short-stalked, without an ocular chamber. Ascospores 42-55 × 6.5-9 $\mu \mathrm{m}$, biseriate, hyaline, fusiform, 1-septate, constricted at the septum, smooth-walled, surrounded by a gelatinous sheath. Asexual morph: Undetermined.

Geographical distribution - Brazil.

Material examined - BRAZIL. Ceará: Ubajara, Ubajara National Park (3050'24''S, 40 $54^{\prime} 17^{\prime} \mathrm{W}$ ), on branch of unidentified woody plant, 3 May 2012, D.A.C. Almeida s.n (HUEFS 131229, holotype designated here).

Notes - Bertiella gelatinosa is easily distinguished from all accepted species by its longer ascospores surrounded by a gelatinous sheath (Table 1). This latter characteristic is common in Massarina species (Aptroot 1998). However, since this genus has been shown to be polyphyletic (Liew\& al. 2002, Zhang\& al. 2009), we place the new species in Bertiella based on the superficial ascomata.

\section{Key to known species of Bertiella}

1. Ascospores surrounded by a gelatinous sheath ................................ B. gelatinosa

1. Ascospores lacking a sheath. 2

2. Ascomata covered with outwardly projecting, long hairs B. ellipsoidea

2. Ascomata not as above.

3. Ascomata wall cephalothecioid B. macrospora

3. Ascomata wall not cephalothecioid 4

4. Ascomata red at apex.... B. rhodospila

4. Ascomata black at apex B. botryosa 
TABLE 1. Synopsis of Bertiella species.

\begin{tabular}{|c|c|c|c|c|c|c|c|c|c|}
\hline \multirow[b]{2}{*}{ Species } & \multicolumn{2}{|l|}{ Ascomata } & \multicolumn{2}{|l|}{ Asci } & \multicolumn{4}{|c|}{ Ascospores } & \multirow[b]{2}{*}{ References } \\
\hline & Shape & $\begin{array}{l}\text { Size }(\mu \mathrm{m}) \\
\text { diam. }\end{array}$ & Shape & $\operatorname{Size}(\mu \mathrm{m})$ & Shape & Septa & $\begin{array}{l}\text { Gelatinous } \\
\text { sheath }\end{array}$ & Size $(\mu \mathrm{m})$ & \\
\hline B. botryosa & Subglobose & 200 & $\begin{array}{l}\text { Cylindric- } \\
\text { clavate }\end{array}$ & $100-110 \times 11-14$ & Fusiform & $1-3$ & Absent & $20-30 \times 5-6$ & Morgan (1904) \\
\hline B. ellipsoidea & Subglobose & $200-250$ & $\begin{array}{l}\text { Cylindric- } \\
\text { clavate }\end{array}$ & $112-160 \times 10-12$ & Ellipsoid & 1 & Absent & 14-189 6-7 & Hyde, et al. (2016) \\
\hline B. gelatinosa & $\begin{array}{l}\text { Discoid to } \\
\text { subglobose }\end{array}$ & $200-550$ & Clavate & $124-188 \times 14-22$ & Fusiform & 1 & Present & $42-55 \times 6.5-9$ & This paper \\
\hline B. macrospora & Subglobose & - & $\begin{array}{l}\text { Cylindric- } \\
\text { clavate }\end{array}$ & $130-150 \times 22$ & Fusiform & 1 & Absent & $22-43 \times 5-9$ & $\begin{array}{l}\text { Eriksson \& Yue } \\
\text { (1986); Mugambi } \\
\text { \& Huhndorf (2009) }\end{array}$ \\
\hline B. rhodospila & Pyriform & $190-440$ & Clavate & $50-85 \times 5-11$ & Fusiform & 3 & Absent & $16-25 \times 3-5$ & Barr\& al. (1986) \\
\hline
\end{tabular}



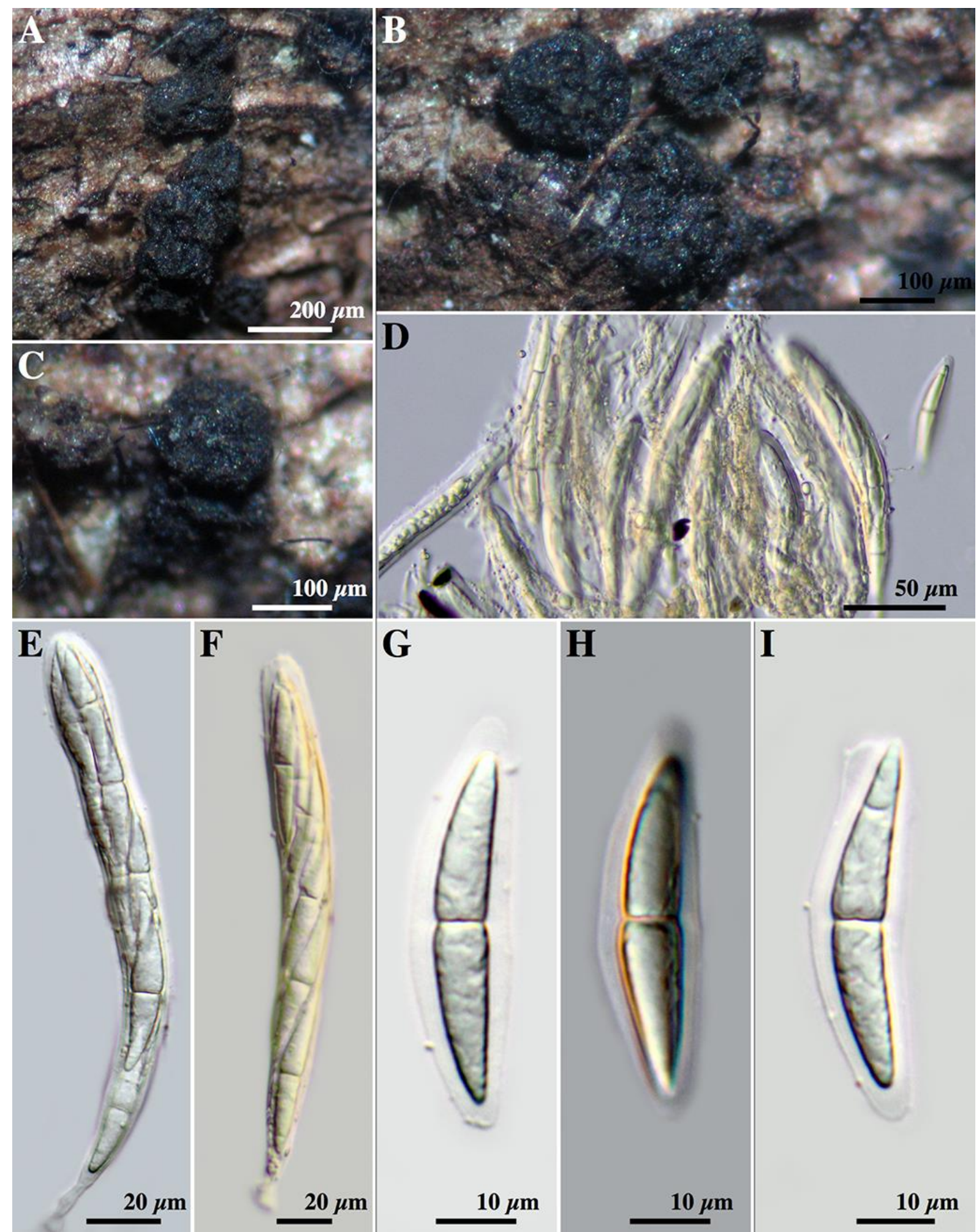

Fig. 1 - Bertiella gelatinosa. A-C. Ascomata. D. Asci with ascospores and pseudoparaphyses. E-F. Asci with ascospores. G-I. Ascospores.

\section{Acknowledgements}

The authors thank the Program of Research of Biodiversity in the Brazilian Semi-arid (PPBIO Semi-arid/Ministry of Technology and Science - proc. 554718/2009-0) for financial support. The first and second authors thank the National Council for Scientific and Technological Development (CNPq) for the Postdoctoral Research Fellowships (proc. 163775/2015-0) and for the grant (proc. 303062/2014-2), respectively. 


\section{References}

Almeida DAC, Gusmão LFP, Miller AN. 2014 - A new genus and three new species of hysteriaceous ascomycetes from the semiarid region of Brazil. Phytotaxa 176, 298-308.

Aptroot A. 1998 - A world revision of Massarina (Ascomycota). Nova Hedwigia 66, 89-162.

Barr ME, Rogerson C, Smith J. 1986 - An annotated catalog of the pyrenomycetes described by Charles H. Peck. Bulletin of the New York State Museum 459, 1-74.

Berkeley MJ. 1876 - Notices of North American Fungi. Grevillea 4, 141-162.

Eriksson O, Yue J - 1986. Bertiella (Sacc.) Sacc. \& Sydow, a synonym of Massarina Sacc. Mycotaxon

GBIF. 2016. Global Biodiversity Information Facility Data Portal., in Editor (ed.)^(eds.), Book Global Biodiversity Information Facility Data Portal.

Hyde KD, Hongsanan S, Jeewon R, Bhat DJ et al. 2016 - Fungal diversity notes 367-490: taxonomic and phylogenetic contributions to fungal taxa. Fungal Diversity 80, 1-270.

Hyde KD, Jones EBG, Liu J-K, Ariyawansa H et al. 2013 - Families of Dothideomycetes. Fungal Diversity 63, 1-313.

Liew EC, Aptroot A, Hyde KD. 2002 - An evaluation of the monophyly of Massarina based on ribosomal DNA sequences. Mycologia 94, 803-813.

Lumbsch HT, Huhndorf SM. 2007 - Outline of Ascomycota. Myconet 13 1-58.

Lumbsch HT, Huhndorf SM. 2010 - Myconet Volume 14. Part One. Outline of Ascomycota2009. Part Two. Notes on Ascomycete Systematics. Nos. 4751-5113. Fieldiana Life and Earth Sciences 1, 1-64.

Morgan A. 1904 - New Species of Pyrenomycetes. The Journal of Mycology 10, 161-162.

Mugambi G, Huhndorf S. 2009 - Molecular phylogenetics of Pleosporales: Melanommataceae and Lophiostomataceae re-circumscribed (Pleosporomycetidae, Dothideomycetes, Ascomycota). Studies in Mycology 64, 103-121.

Saccardo PA, Sydow P. 1899 - Supplementum Universale, Pars IV. Sylloge Fungorum.

Sydow H, Sydow P. 1906 - Referate und kritische Besprechungen. Annals Mycologici 4, 453-469.

Thiessen F, Sydow H. 1915 - Die Dothideales. Kritisch-systematische Originaluntersuchungen. Annales mycologici 13, 147-746.

Tian Q, Liu JK, Hyde KD, Wanasinghe DN et al. 2015 - Phylogenetic relationships and morphological reappraisal of Melanommataceae (Pleosporales). Fungal Diversity 74, 267324.

Zhang Y, Crous PW, Schoch CL, Hyde KD. 2012a - Pleosporales. Fungal Diversity 53, 1-221.

Zhang Y, Crous PW, Schoch CL, Hyde KD. 2012b. Pleosporales. Fungal Diversity 53, 1-221.

Zhang Y, Wang HK, Fournier J, Crous PW et al. 2009 - Towards a phylogenetic clarification of Lophiostoma / Massarina and morphologically similar genera in the Pleosporales. Fungal Diversity 38, 225-251. 